Meta

Journal des traducteurs

Translators' Journal

\title{
English Core Library List for Translators in the Sciences and Technology
}

\section{Vladimir N. Nekrassoff}

Volume 25, numéro 1, mars 1980

La documentation

URI : https://id.erudit.org/iderudit/003713ar

DOI : https://doi.org/10.7202/003713ar

Aller au sommaire du numéro

Éditeur(s)

Les Presses de l'Université de Montréal

ISSN

0026-0452 (imprimé)

1492-1421 (numérique)

Découvrir la revue

Citer cet article

Nekrassoff, V. N. (1980). English Core Library List for Translators in the Sciences and Technology. Meta, 25(1), 111-125. https://doi.org/10.7202/003713ar d'utilisation que vous pouvez consulter en ligne. 


\title{
English Core Library List for Translators in the Sciences and Technology
}

\author{
Dr. Vladimir N. NekrassofF \\ translator, \\ Ottawa
}

The following core library list represents an attempt to provide a basic list of handbooks, encyclopedias, unilingual English dictionaries, and some basic textbooks for translators in the sciences and technology. The list might also be useful for university translation schools.

The approximate total cost of a collection of translation reference works and two- (or multi-) language dictionaries used by specialized translators can easily amount to $\$ 5000$, with annual additions (and journals) costing around $\$ 1000$.

Individual translators can use this list as a guide to select those materials must useful to their particular situation, depending on financial restrictions and emphasis on particular aspects of their work.

Note : All prices are given in Canadian currency. Prices quoted between brackets are approximate. The following abbreviations have been used.

\begin{tabular}{|c|c|}
\hline McGraw-Hill, & $\begin{aligned} \text { in Canada : } & \text { McGraw-Hill Ryerson Ltd., } \\
& 330 \text { Progress Avenue, } \\
& \text { Scarborough, Ont. M1P 2Z5 } \\
\text { U.S.A. : McGraw-Hill International Book Company, } & 1221 \text { Avenue of the Americas, } \\
& \text { New York, N.Y., } 10020\end{aligned}$ \\
\hline $\begin{array}{l}\text { VNR : Van Nostrand } \\
\text { Reinhold Ltd., }\end{array}$ & $\begin{aligned} \text { in Canada : Van Nostrand Reinhold Ltd., } \\
\\
1410 \text { Birchmount Road, } \\
\text { Scarborough, Ont. M1P 2E7 } \\
\text { U.S.A. : Van Nostrand Reinhold Company, } \\
\\
\text { 450 West 33rd Street, } \\
\text { New York, N.Y., } 10001\end{aligned}$ \\
\hline W. : Wiley, & $\begin{aligned} \text { in Canada : John Wiley and Sons Canada Ltd., } & \\
& 22 \text { Worcester Road, } \\
& \text { Rexdale, Ont. M9W 1L1 } \\
\text { U.S.A. : Wiley-Interscience, } & 605 \text { Third Avenue, } \\
& \text { New York, N.Y., 10016 }\end{aligned}$ \\
\hline
\end{tabular}


BONNEY, J.B., and J.P. FREIN, Handbook of Construction Management and Organization, 688 p., 266 illus. [\$43.25], VNR.

Covering every facet of construction management from site investigation to contract completion and settlement, this book is a veritable * tool kit » of sound business techniques used in the world of contracting.

DUMOUCHI, J., Dictionary of Development Terminology, 1975, 288 p. [\$18.50], McG-H. This dictionary provides ready access to standard definitions of over 2000 of the most frequently used terms in housing and community development.

HARRIS, C., Dictionary of Architecture and Construction, 1975, 512 p., [\$45], McG-H. Prepared by a staff of fifty-two experts, this authoritative and comprehensive dictionary provides definitions of terms encountered in the everyday practice of architecture and construction.

SAYLOR, H.H., Dictionary of Architecture, 1963, 221 p. [\$8], W.

WHITTICK, A., Encyclopedia of Urban Planning, 1974, 1204 p., 592 illus. [\$50], McG-H. This one-volume encyclopedia covers all aspects of urban and regional planning. It offers what is needed in comprehensive surveys before planning. Economic and social questions are considered.

Astronomy, cf. Physics

Business

ALLEN, L., The Management Profession, 1964, 388 p., [\$19], McG-H...

This analysis of basic management principles and techniques covers the entire range of management practice. Topics discussed include a precisely defined vocabulary of professional management.

BARTON, R., Handbook of Advertising Management, 1970, 1090 p. [\$40], McG-H.

This book considers every aspect of modern advertising management including organization, planning, media, use of copy in media, research, legal matters, etc. A Glossary of Advertising defines hundreds of terms used in the industry.

CLIFTON, H.D., and T. LUCEY, Accounting and Computer Systems, 192 p. [\$18.75], VNR. Accounting and information systems. Systems investigation. Computer hardware and computer software. Design of data processing systems. Implementation of data processing systems. Application of computers.

COLBERT, D.A., Computers and Management for Business, 416 p. [\$17.50], VNR. This book concentrates on computers and their impact on business, management, business people, and to a lesser extent, society and social implications. Glossary, bibliography, index.

DAVIDSON, S., and R. WEIL, Handbook of Modern Accounting, 2nd Ed., 1977, 1536 p. [\$40], McG-H.

Thoroughly revised, this new edition provides the latest information on developments in accounting procedures for earning forecasts, and compound interest applications; statistical concepts in auditing; inflation accounting; foreign exchange; and human resource accounting.

DILLON, J., Handbook of International Direct Marketing, 1977, 420 p. [\$33], McG-H. This book covers all the major aspects of international direct marketing. The topics are : direct marketing and marketing mix, creative design, international mailing lists, testing, using computers, statistical evaluation, public relations, translations, multilingual printing letter shops.

DREYFUSS, H., Symbol Sourcebook : An Authoritative Guide to International Graphic Symbols, 1972, 320 p. [\$40], McG-H.

This handbook is the first single reference to graphic symbols used internationally in business, industry, the sciences, and all walks of life. 
FERBER, R., Handbook of Marketing Research, 1974, 1344 p. [\$50], McG-H.

From testing a new product in the market place and measuring the impact of advertising, to model building in marketing and today's most effective decision information systems, this handbook constitutes a highly comprehensive reference on marketing research methods.

HEYEL, C., Encyclopedia of Management, 2nd Ed., 1182 p., 135 illus. [\$43.25], VNR. Tested ideas and techniques in every important management area, from job enrichment programs to process analysis and process engineering.

MAYNARD, H., Handbook of Business Administration, 1967, 2048 p. [\$50], McG-H.

The foremost experts in the field have contributed to this monumental reference work which gives authoritative information on all aspects of management practice. It discusses in depth such areas as organization, activity area management, office management, systems and data processing, and international business.

MODER, J.J., and S.E. ELMAGHRABY, Handbook of Operations Research : Foundation and Fundamentals, vol. I [\$40.75], Models and Applications, vol, II [\$40.75], 605 p. plus index, VNR.

This handbook provides an authoritative, concise and comprehensive treatment of theory and applications of operations research. Vol. $I$ is a definite reference source on fundamental concepts and methodologies. Vol. II provides comprehensive presentation of specific applications.

Chemistry

BENNETT, H., Concise Chemical and Technical Dictionary, 3rd Ed., 1974, 1175 p. [\$45], Chemical Publishing.

This unique dictionary contains 75000 definitions, which cover a wide range of terms from chemistry and related areas. In addition, there are short sections on the nomenclature of organic chemistry, names and formulas of radicals occurring in organic compounds, references for fuller and additional definitions, and technical tables.

BRITT, K.W., Handbook of Pulp and Paper Technology, 2nd Ed., 724 p. [\$41.95], VNR. A comprehensive survey of technological achievements in the pulp and paper industry, this book covers every aspect from sources of raw material to uses of paper.

CAHN, R.S., An Introduction to Chemical Nomenclature, 4th Ed., 1974, 128 p. [\$8.50], Halsted/Wiley.

CONSIDINE, D., Chemical and Process Technology Encyclopedia, 1974, 1184 p. [\$48], McG-H.

In covering the gamut of chemistry, chemical engineering, and process engineering, this one-volume encyclopedia serves the needs of translators and others who cannot afford a multi-volume reference set in their private library.

DAVIES, C.W., and A.M. JAMES, Dictionary of Electrochemistry, 1976, 246 p. [\$24], W. This handy reference book provides sketches of important concepts in electrochemistry.

HAWLEY, G.G., Condensed Chemical Dictionary, 9th Ed., 970 p. [\$40.75], VNR.

This dictionary is crammed with compact, accurate summaries of thousands of chemicals and chemical phenomena. Energy and its sources are emphasized in this new edition.

GRANT, J., Hackh's Chemical Dictionary, 4th Ed., 1969, 1040 p. [\$50], McG-H. This new edition reflects the unprecedented advances made in chemistry and related sciences in recent years. It contains about 80000 terms.

HAMPEL, C.A., and G.G. HAWLEY, Encyclopedia of Chemistry, 3rd Ed., 1216 p. [\$49.50], VNR.

Over 800 articles highlight industrial uses and applications of chemicals or classes of chemicals. Environmental chemistry and the chemistry of life processes are emphasized in this new edition.

HAMPEL, C.A., and HAWLEY, G.G., Glossary of Chemical Terms, 288 p. [\$18.75], VNR. For anyone who needs basic definitions of chemical terminology, this glossary is an 
ideal reference. Containing 2000 concise, to-the-point entries, it covers terms used in the subdivisions of chemistry, along with those in common usage in the chemical industries.

KENT, J.A., Riegel's Handbook of Industrial Chemistry, 7th Ed., 902 p., 824 illus. [\$48], VNR. This handbook covers the major segments of the chemical process industries.

RUBIN, A.J., Chemistry of Wastewater Technology [\$34.50], VNR.

Latest chemical research on water pollution control is presented in this symposium proceedings. Covers subjects as diverse as disinfection, adsorption and nutrient removal in municipal and industrial wastewaters.

SALTMAN, D., Paper Basics : Forestry, Manufacture, Selection, Purchasing, Mathematics and Metrics, Recycling, 226 p. plus index, 108 illus. [\$13.75], VNR.

An introduction for professionals in several fields, this book is thoroughly up-to-date, covering the newest technological advances and exploring the urgent challenges of environmental and energy conservations in paper production.

Computers

ASHLEY, Ruth, and N. Fernandez JUDI, Job Control Language, 1978, 157 p., glossary, [\$6.50], W.

GREENSTEIN, C., Dictionary of Logical Terms and Symbols, 150 p. [\$13.75], VNR.

A complete dictionary of alternative logical notations, operations and terms. Features abbreviations of standard notational concepts, rules of inference expressed in more than one notational system, and modal, non-modal and binary truth tables and truth trees.

JORDAIN, P., Condensed Computer Encyclopedia, 1969, 448 p. [\$28], McG-H.

Arranged alphabetically and copiously cross-referenced, this work explains the bewildering array of terms, items, technical details, interpretive languages, etc., connected with computers.

RALSTON, A., Encyclopedia of Computer Science, 1521 p. [\$75], VNR.

This one-volume, basic reference combines the expertise of more than 200 respected authorities in over 480 articles with more than 1000 illustrations, tables, and charts.

SIPPL, C.J., Communications Dictionary, 544 p. [\$24.95], VNR.

Providing instant access to over 14000 terms, this dictionary is a compilation of definitions, concept explanations and language interpretations of the terms, acronyms and abbreviations used in information processing and transmission.

YEARSLEY, R., and R. GRAHAM, Handbook of Computer Management, 1973, 328 p. [\$24], W.

Survey of computing systems ; buying computer services; managing the data processing function; applications of computers in businesse.

YEH, Raymond T. (Ed.), Current Trends in Programming Methodology, Vol. 4, Data Structuring, 321 p. [\$25], 1978, Prentice-Hall.

Earth Sciences

AMERICAN GEOLOGICAL INSTITUTE, Dictionary of Geological Terms, revised ed., 1976,427 p. [\$4.50], Anchor/Doubleday.

COLE, Gerald A., Textbook of Limnology, 2nd Ed., 426 p., 1979 [\$22.75], C.V. Mosby Co.

JACKSON, K., Textbook of Lithology, 1970, 484 p. [\$27] McG-H.

Detailed descriptions and vivid illustrations contribute to making this book, which covers both sedimentary and metamorphic rocks, an intelligent source for aid in efficiently determining the correct interpretation of the observable features of rock genesis.

KNAUSS, John A., Introduction to Physical Oceanography, 1978, 338 p. [\$35], Prentice-Hall.

McGraw-Hill Encyclopedia of the Geological Sciences, 914 p., 1979 [\$37.50], McG-H. 
MONKHOUSE, F.J., and J. SMALL, A Dictionary of Physical Geography, 1977, 250 p. [cloth : \$24], [paper : \$8.50], W.

Definitions, methods of field survey, map projections.

MOORE, W.G., A Dictionary of Geography, 1969, 246 p., 88 illus., Frederick A. Praeger. Definitions and explanations of terms used in physical geography.

PRESS, Frank, and Raymond SIEVER, Earth, 2nd Ed., 1978, 649 p. [\$20.50], Freeman.

ROBERTS, W., G. RAPP jr., and J. WEBER, Encyclopedia of Minerals, 694 p., 940 fullcolor illus. [\$86.95], VNR.

The most authoritative information available on all known and authenticated mineral species. Includes chemical, physical, crystallographic, X-ray, optical and geographical data in comprehensive detail.

ROBINSON, Arthur, Randall SALE, and Joel MORRISON, Elements of Cartography, 1978, 448 p. [\$22.50], W.

STAMP, L.D., Dictionary of Geography, 1966, 492 p. [\$13.50], W.

STRAHLER, Arthur, and Alan H. STRAHLER, Modern Physical Geography, 1978, 502 p. $[\$ 19.00], W$.

ZOTTOLI, Robert, Introduction to Marine Environments, 2nd Ed., 1978, 252 p. [\$14.50], C.V. Mosby Co.

Cf. also R.W. Fairbridge under Special Reference.

Economics

BOULDING, K., Economics as a Science, 1970, 160 p. [cloth : \$11], [paper : \$8], McG-H. The scope and setting of economics, and the place it occupies in the intellectual and professional community are outlined in this book.

DESAL, M., Applied Econometrics, 1976, 256 p. [\$20], McG-H.

This guide to econometrics emphasizes the connection between theory and application.

GREENWALD, D., The McGraw-Hill Dictionary of Modern Economics, 2nd Ed., 1973, 800 p. [\$30], McG-H.

This reference provides clear, concise definitions of approx. 1400 frequently used economic terms, explaining the key concept of each term, and giving references to both current and original sources of information.

MADDALA, G., Econometrics, 1977, 576 p. [\$18.50], McG-H.

This book sheds new light on a complex topic by stressing both theory and practical application in a comprehensive approach. Important topics discussed are : proxy variables, limited and dependent variables, missing observations and aggregation problems, and analysis of grouped data.

McCONNELL, C., Economics : Principles, Problems and Policies, 6th Ed., 1975, 919 p. [\$19], McG-H.

Energy

HUNT, D., The Energy Dictionary, 512 p. [\$22.50], VNR.

This dictionary provides an up-to-date concise compilation of the salient terms associated with the broad field of energy. Approx. 4000 entries are suplemented with 300 charts, graphs, process diagrams and photographs.

LOFTNESS, R.L., Energy Handbook, 640 p. [\$56.25], VNR.

A major compilation and survey of energy resources, costs, conservation, efficiency, depletion, storage, transport, consumption patterns, conversion technologies, and environmental factors. Profusely illustrated with tables, graphs, maps and other visual devices. 
McGraw-Hill Encyclopedia of Energy, 1976, 750 p. [\$30], McG-H.

This encyclopedia is designed to provide better understanding of the issues and the technological, economic, political, and social problems surrounding energy and its use. This first part contains six feature articles which give an overview of the worldwide energy situation. The second part features more than 300 alphabetically arranged articles dealing with the different areas of the energy problem.

PESKO, C., Solar Directory, 624 p. [\$23], VNR.

This directory gives information on work in the solar field throughout the world.

YEN, T.F., Science and Technology of Oil Shale, 226 p. [\$37.50], VNR.

Engineering

AZAD, H., Industrial Wastewater Management Handbook, 1976, 608 p. [\$35], McG-H.

This book deals with the water pollution control problems of six major industries : Chemical, Petroleum, Metals, Pulp and Paper, Power, and Food and Beverage.

BLAND, W., and R. DAVIDSON, Petroleum Processing Handbook, 1967, 1102 p. [\$55]. McG-H.

A comprehensive source book.

BRADY, G., and H. CLAUSER, Materials Handbook, 11th Ed., 1977, 1038 p. [\$35], McG-H. This handbook provides practical information on more than 13000 materials and substances. For each substance, the authors give precise details of its general nature, composition, production, major characteristics, uses, and commercial designations or trade names.

BAUMEISTER, T., and L. MARKS, Standard Handbook for Mechanical Engineers, 1967, 2456 p. [\$48], McG-H.

Provides invaluable information for translators in this field.

BRATER, E., and H. KING, Handbook of Hydraulics, 6th Ed., 1976, 608 p. [\$35], McG-H. Revised and updated, this new edition features tables, particularly those for pipe and open channel problems. A new chapter deals with computer programming to solve hydraulic problems.

CHOW, V., Handbook of Applied Hydrology, 1964, 1468 p. [\$60], McG-H.

This comprehensive presentation of the principles and data required for the study and management of water and water resource projects discusses the fundamental sciences underlying hydrology and the hydrologic cycle, with due attention to applications in different areas, and flood and flow control.

CONSIDINE, D., Encyclopedia of Instrumentation and Control, 1971, 816 p. [\$48], McG-H. This work coordinates instrumentation and control technology. The explanations are clear, practical and fully illustrated. An appendix lists the subjects covered in logical outline form.

CONSIDINE, D., Energy Technology Handbook, 1977, 1859 p. [\$36], McG-H.

This handbook concentrates on the important issue of energy - its availability, its use, its effects. It contains separate sections on each of the major sources of energy : coal, gas, petroleum, chemical fuels, nuclear, solar, and geothermal energy as well as hydropower.

CONSIDINE, D., and S. ROSS, Handbook of Applied Instrumentation, 1964, 1156 p. [\$55], McG-H.

A definite summation of how instruments are used to control machines, operations, processes, and industries, this book provides a thorough analysis of the basic types of variables subject to instrumentation and evaluates the ways of measuring them.

CONSIDINE, D., Process Instruments and Controls Handbook, 2nd Ed., 1974, 1344 p. [\$50], McG-H.

This reference volume, covering the design and operation of measurement and automatic control systems, reflects the new developments and changes that have occurred in the process fields. 
COOMBS, C., Basic Electronic Instrument Handbook, 1972, 823 p. [\$36], McG-H.

This comprehensive reference contains basic background for all instrumentation.

COOPER, William David, Electronic Instrumentation and Measurement Techniques, 1978, 500 p. [\$22.50], Prentice-Hall.

ETHERINGTON, H., Nuclear Engineering Handbook, 1958, 1882 p. [\$45], McG-H.

This comprehensive coverage of nuclear engineering details nuclear theory, engineering principles, and techniques, and provides helpful reference material [N.B. No more recent work is known to the author.]

FINK, D., Electronics Engineers' Handbook, 1975, 2000 p. [\$50], McG-H.

This exhaustive compilation contains more than 2000 illustrations, 2500 bibliographical entries, and 2100 formulas and equations. This handbook is a reliable reference manual.

FINK, D., and J. CARROLL, Standard Handbook for Electrical Engineers, 10th Ed., 1968, 2596 p. [\$52], McG-H.

This handbook includes modern and sophisticated techniques for computer control of power generation and distribution along with conventional data on wiring and switchgear ; it contains a functional index.

GRUENBERG, E., Handbook of Telemetry and Remote Cotrol, 1967, 1337 p. [\$60], McG-H.

This handbook comprehensively covers the techniques and applications of measurement and control from a distance, including applications to industry, automation, nuclear power, and space exploration.

HANDLEY, William (Ed.), Industrial Safety Handbook, 2nd Ed., 1977, 480 p. [\$30], McG-H.

HAVERS, J., and F. STUBBS, Handbook of Heavy Construction, 2nd Ed., 1971, 1440 p. [\$60], McG-H.

This source book codifies the basics of heavy construction, from tunneling to skyscraper erection.

INSTITUTE OF ELECTRICAL AND ELECTRONIC ENGINEERS, Inc., IEEE Standard Dictionary of Electrical and Electronic Terms, 1972, 716 p. [\$28], W.

LITKINS, P., Elements of Engineering Mechanics, 1973, 484 p. [\$25], McG-H.

An integrated treatment of the statics and dynamics of particles and rigid bodies is provided in this book.

MARKUS, J., Electronics and Nucleonics Dictionary, 3rd Ed., 1966, 650 p. [\$30], McG-H. Containing nearly 16500 terms and 1000 illustrations, this standard reference work serves as a definite and approachable key to the language of electronics and nucleonics. Lasers are represented with the latest terms.

MERRITT, F., Building Construction Handbook, 3rd Ed., 1975, 992 p. [\$47.50], McG-H. This singularly comprehensive handbook is a concise, reliable guide to every facet of modern design and construction.

MERRITT, F., Standard Handbook for Civil Engineers, 2nd Ed., 1976, 1344 p. [\$50], McG-H. This practical reference guide to civil engineering provides the most important numerical and descriptive data on such areas as bridge, highway, railroad, tunnel, and harbor construction as well as environmental engineering.

PERRY, R., Engineering Manual : A Practical Reference Book of Data and Methods in Architectural, Chemical, Civil, Electrical, Mechanical, and Nuclear Engineering, 3rd Ed., 1976, 800 p. [\$25], McG-H.

This handbook makes vital engineering information accessible by bringing together in one volume the most commonly used methods and data in the fields mentioned in the title. Two new sections have been added : environmental engineering, and energy conservation.

PERRY, R., and C. CHILTON, Chemical Engineers Handbook, 5th Ed., 1973, 1920 p. [\$50], McG-H.

This completely updated edition of the chemical engineers" « bible » provides facts, figures, methods and data needed by the chemical engineer. 
TSYTOVTCH, N., Mechanics of Frozen Ground, 1975, 448 p. [\$45], McG-H.

This translation of the 1973 Russian edition will be of use to anyone whose work entails a consideration of the peculiar characteristics of frozen soil.

WARD, R., Principles of Hydrology, 2nd Ed., 1975, 344 p. [\$24], McG-H.

Extensively revised and updated, this handbook is an introductory survey of the occurrence, distribution, and movement of water. Generously illustrated, this book is an important addition to the reference library of all those in the earth sciences.

\section{Environment}

ALLABY, M., A Dictionary of the Environment, 532 p. [\$25.95], VNR.

This dictionary defines and explains 6000 words and phrases used in all sciences that relate to the environment. It records environmental terms and concepts as these are understood and used at present.

BERRY, F., et al., Handbook of Meteorology, 1945, 1116 p. [\$50], McG-H.

This reference book covers the entire subject of meteorology and presents a wealth of authoritative information. Each section is profusely illustrated with photographs, maps, sketches, and line drawings. [N.B. No more recent work is known to the author.]

McEVOY, J., and T.M. DIETZ, Handbook of Environmental Planning : The Social Consequences of Environmental Change, 1977 [\$25], W.

Provides guidelines and methods for preparing and reviewing reports on social aspects of environmental change; includes definitions of terms.

McGraw-Hill Encyclopedia of Environmental Science, 1974, 768 p. [\$30], McG-H. This reference work contains 300 articles and over 600 illustrations covering the span of environmental science.

MONKHOUSE, J., and John SMALL, A Dictionary of the Nature Environment, 1978, 320 p. [\$24.50], Halsted (W.).

\section{Library Science}

GATES, J., Guide to Use of Books and Libraries, 3rd Ed., 1974, 288 p. [cloth : \$11], [paper : \$7], McG-H.

This brief but comprehensive guide covers the many kinds of library materials found primarily in the academic library. Each chapter includes definition of terms.

KATZ, W., Introduction to Reference Work, Vol. I : Basic Information Sources, 2nd Ed., 1974,444 p. [\$15], McG-H.

Volume I covers in depth the main features of encyclopedias, dictionaries, handbooks, and other reference books, and demonstrates their principles of application in a series of exemplary problems and case studies.

KATZ, W., Introduction to Reference Work, Vol. II : Reference Services, 2nd Ed., 1974, 256 p. [\$14], McG-H.

This volume describes the reference librarian's specific duties and responsibilities. The emphasis is on updating all bibliographical data, new technological processes, and policies.

Life Sciences

COCKRUM, E.L., Introduction to Mammalogy, 1962, 455 p. [\$16], W.

DASMANN, R.F., Wildlife Biology, 1964, 231 p. [\$16], W. Wildlife habitat; characteristics of wildlife populations; methods for studying wildlife; references; index.

DENNEY, R.C., A Dictionary of Chromatography, 1976, 191 p. [\$16], W.

This volume lists terms, nomenclature, and detectors under their most common form while cross-referencing them to as many of their variations as possible. 
EVANS, A., Glossary of Molecular Biology, 1975, 55 p. [\$11], W. Readers of the specialized literaturs of molecular biology who are new to this field will find this convenient glossary invaluable.

FIRTH, F.E., Encyclopedia of Marine Resources, 740 p., 380 illus. [\$35.50], VNR. Covering every type of commercial fish, this volume presents a geographical study of commercial fisheries and related technologies.

FORBES, R.D. and A.B. MEYER, Forestry Handbook, 1955, 1201 p. [\$301], W. A handbook for professionals working in forestry, conservation and in other technical and administrative phases of these and allied fields; it organizes for ready reference the facts, techniques, and working methods needed to answer the questions and solve the problems of practical forestry.

FROBISHER, M., et al., Fundamentals of Microbiology, 9th Ed., 1974, 850 p. [\$19], Saunders ; glossary ; index.

GRAY, A., Manual of Botany, 8th Ed., 1700 p. [\$41.25], VNR.

$A$ handbook of flowering plants of Canada (and central and northeastern U.S.). Includes an analytical key to families; descriptive flora; glossary of terms; and indices to English, Latin, French-Canadian and colloquial names of families, genera, and species.

GRAY, P., Dictionary of Biological Sciences, 622 p. [\$28.25], VNR. This work provides over 40000 definitions in the life sciences.

GRAY, P., Encyclopedia of Microscopy and Microtechnique, 684 p., 500 illus. [\$43.75], VNR. An encyclopedia of interest to life sciences workers; it provides thorough coverage of microscopic instruments, techniques and applications.

GRAY, P., Encyclopedia of the Biological Sciences, 2nd Ed., 1142 p. [\$40.75], VNR. A commanding authority by any standards, this impressive volume includes over 800 articles. Every significant discipline from botany through zoology and the life sciences is identified and scrutinized with concision.

HOAGLAND, Mahlon B., The Roots of Life : A Layman's Guide to Genes, Evolution and the Ways of Cells, 1977, 162 p. [\$11], Houghton Mifflin.

KELETI, G., and W.H. LEDERER, Handbook of Micromethods for the Biological Sciences, 166 p., illus. [\$16.25], VNR.

A book of 102 methods, each specifically detailing a biochemical or microbiological procedure for preparation or analysis.

KRUMBEIN, W.E., Environmental Biogeochemistry and Geomicrobiology (3-volume set) [\$43.25], VNR.

Some of the latest research in this new interdisciplinary field is included in this comprehensive 3-volume set. Vol. 1 : The Aquatic Environment. Vol. 2 : The Terrestrial Environment. Vol. 3 : Methods, Metals and Assessment.

KUTSKY, R.J., Handbook of Vitamins and Hormones, 278 p. [\$21.25], VNR.

A concise reference containing most of the known information about vitamins, hormones, and their inter-relationships.

LEE, S.D., Biochemical Effects of Environmental Pollutants, 478 p. [\$32.25], VNR. This book provides a basic understanding of the ways in which environmental pollutants affect plant and animal life.

LEVITAN, Max, and Asley MONTAGU, Textbook of Human Genetics, 2nd Ed., 1977, 1012 p. [\$25], Oxford University Press.

LEWIS, Walter H., Ecology Field Glossary : A Naturalist's Vocabulary, 1977, 152 p. [\$19], Greenwood (Westport, CT, USA).

McCONNAUGHEY, Bayard H., Introduction to Marine Biology, 3rd Ed., 1978, 624 p. [\$21], C.V. Mosby.

McGraw-Hill Dictionary of the Life Sciences, 1976, 992 p. [\$25], McG-H

A practical reference guide to the vocabulary of the biological sciences and related disciplines, this new dictionary contains over 20000 terms and definitions encompassing 
49 different fields of science. The ample cross-referencing of synonyms and the more than 800 illustrations enhance the usefulness of this work.

McGraw-Hill Encyclopedia of Food, Agriculture and Nutrition, 1977, 732 p. [\$29.50], McG-H.

McKINNEY, R., Microbiology for Sanitary Engineers, 1962, 293 p. [\$27.50], McG-H.

PELCZAR, jr., M., R. REID, and E. CHAN, Microbiology, 4th Ed., 1977, 960 p. [\$25], McG-H.

The newest developments in microbiology are reflected in this revision. Included are discussions of microbial classification and genetics, research developments in aquatic microbiology, and microorganisms as a source of food supplements.

RICHEY, C., et al., Agricultural Engineer's Handbook, 1961, 880 p. [\$40], McG-H.

SINGLETON, Paul, and Diana SAINSBURY, Dictionary of Microbiology, 1978, 482 p., illus. [\$55], W.

STENESH, J., Dictionary of Biochemistry, 1975, 344 p. [\$30], W.

This dictionary contains approximately 12000 entries drawn from over 200 text and reference books and from the research literature of biochemical journals.

STODDARD, Charles H., Essentials of Forestry Practice, 3rd Ed., 1978, 387 p. [\$16.50], W.

WESTCOTT, C., Plant Disease Handbook, 3rd Ed., 860 p. [\$29.50], VNR.

This book shows how to diagnose and control over 2100 diseases common to home gardens, greenhouses and farms. Glossary.

WILLIAMS, R.J., and E.M. LANSFORD, Encyclopedia of Biochemistry, 1967, 876 p., VNR. A commanding authority by any standards.

Mathematics and Statistics

BURINGTON, R., and D. MAY, Handbook of Probability and Statistics, 2nd Ed., 1969, 416 p. [\$20], McG-H.

This guide to statistical applications includes material on the impact of computers on a broad range of fields, order statistics, statistics, sampling, reliability, regression theory, and other topics.

GELLERT, W., et al., VNR Concise Encyclopedia of Mathematics, 810 p., illus. [\$18.75], VNR.

Every specialized area of mathematics is lucidly explained in this storehouse of information. It describes the inter-relationships between the various mathematical branches that have emerged from antiquity to our own time.

JAMES, Glenn, and C. ROBERT, Mathematics Dictionary, 518 p., illus. [\$22.50], VNR. Defining 8000 terms, this book features expanded coverage of probability and statistics while continuing to include important topics in a wide variety of mathematical specialities. Contains French-English, German-English, and Russian-English glossaries.

JAMISON, R., Introduction to Computer Science Mathematics, 1973, 267 p. [\$18], McG-H. The major mathematical concepts essential to data processing, computer programming and computer design are presented in this book, which uses set theory and functional concepts throughout.

KORN, G., and T. KORN, Manual of Mathematics, 1967, 391 p. [\$15], McG-H. This handbook introduces modern mathematical methods, and presents connected outlines of basic mathematical subjects.

KORN, G., and T. KORN, Mathematical Handbook for Scientists and Engineers, 2nd Ed., 1968,1152 p. [\$48], McG-H. A commanding authority.

MASSEY, L., Probability and Statistics, 1970, 256 p. [\$18], McG-H.

MERRITT, F., Mathematical Manual, 1962, 320 p. [\$29], McG-H.

This manual explains every major phase of modern mathematics applicable to problems in business, engineering, and the sciences. 
Medicine

- Allergy and Immunology

PATTERSON, R., Allergic Diseases : Diagnosis and Management, 1972 [\$27.50], Lippincott.

- Anatomy

WARWICK, R., and P.L. WILLIAMS, Gray's Anatomy, 1973 [\$56], Saunders.

GRANT, J.C.B., Grant's Atlas of Anatomy, 1978 [\$34.95], Williams and Wilkins.

BASMAJIAN, J.V., Grant's Method of Anatomy, 1975 [\$26.75], Williams and Wilkins.

- Communicable Diseases

BENENSON, A.S., Control of Communicable Diseases in Man, 1975 [\$4.20], Am. Public Health Assocn.

- Dentistry

COOPER, J.R.C., Dental Problems of Medical Practice, 1976 [\$18.75], Heineman.

- Dermatology

DOMOKOS, A.N., Andrew's Diseases of the Skin, 1971 [\$39.10], Saunders.

STEWART, W.D., et al., Dermatology : Diagnosis and Treatment of Cutaneous Disorders, 1974 [\$33.95], Mosby.

- Diagnosis

CONN, H.F., and R.B. CONN, jr., Current Diagnosis, 1977 [\$30.90], Saunders.

KRUPP, M.A., et al., Current Medical Diagnosis and Treatment, 1978 [\$19.95], Lange.

- Emergencies

COHEN, A.S., Medical Emergencies : Diagnosis and Management Procedures, 1977 [\$15], Little, Brown.

SCHNEEWIND, J.H., Medical and Surgical Emergencies, 1973 [\$9.50], Yr. Bk. Med.

DREISBACK, R.H., Handbook of Poisoning Diagnosis and Treatment, 1977 [\$9.20], Lange.

- Family, Marriage, and Sexuality

BELLIVEAU, F., and L. RICHTER, Understanding Human Sexual Inadequacy, 1970 [\$1.25], Bantam.

DUVALL, E.M., Marriage and Family Development, 1977 [\$14.95], Lippincott.

KAPLAN, H.S., New Sex Therapy : Active Treatment of Sexual Dysfunction, 1974 [\$23], Quadrangle.

MINUCHIN, S., Families and Family Therapy, 1974 [\$10], Harvard University Press.

- Family Medicine

BARBER, J.H., and F.A. BODDY, General Practice Medicine, 1975 [\$13.50], ChurchillLivingstone.

FRY, J., et al., Textbook of Medical Practice, 1976 [\$28.75], MTP Press.

MEDALIE, J.H., Family Medicine : Principles and Applications, 1978 [\$19.25], Williams and Wilkins.

RAKEL, R.E., Principles of Family Medicine, 1977 [\$16.95], Saunders.

- Forensic Medicine

SIMPSON, K., Forensic Medicine, 1974 [\$18], E. Arnold. 
- Growth and Development

ERICKSON, E.H., Childhood and Society, 1963 [\$3.45], Norton.

LIDZ, T., The Person: His and Her Development Throughout the Life Cycle, 1976 [\$14.95], Basic

- Gynecology

BELLER, F.K., et al., Gynecology : A Textbook for Students, 1974 [\$20], Springer.

NOVAK, E.R., et al., Textbook of Gynecology, 1975 [\$35.50], Williams and Wilkins.

- Industrial Medicine

ZENC, C., Occupational Medicine : Principles and Practical Applications, 1975 [\$60.50], Year Bk. Med.

- Internal Medicine

BEESON, P.B., and W. MCDERMOTT, Textbook of Medicine, 1975, $\$ 37.50$, Saunders.

HARVEY, A.M., et al., Principles and Practice of Medicine, 1976 [\$40.85], Appleton-CenturyCrofts.

THORN, G.W., et al., Harrison's Principles of Internal Medicine, 1977 [\$45.60], McG-H.

- Laboratory Medicine

EASTHAM, R.D., Biochemical Values in Clinical Medicine, 1975 [\$9.85], Williams and Wilkins.

WALLACH, J., Interpretation of Diagnostic Tests, 1978 [\$11.50], Brown.

- Nutrition.

BURTON, B.T., Human Nutrition : A Textbook of Nutrition in Health and Disease, 1976 [\$11.95], McG-H.

ONTARIO DIETETIC ASSOCIATION, Diet Manual, 1977 [\$8.50], Ontario Hospital Association.

- Obstetrics

PRITCHARDS, J.A., and P.C. MacDONALD, William's Obstetrics, 1976 [\$37.95], AppletonCentury-Crofts.

- Oncology

UNIVERSITY OF ROCHESTER, School of Medicine and Dentistry, Clinical Oncology for Medical Students and Physicians : A Multidisciplinary Approach, 1974 [\$2], American Cancer Society (Rochester, N.Y., U.S.A.).

- Ophtalmology

JACKSON, C.R., Eye in General Practice, 1975 [\$18], Churchill-Livingstone.....

NEWELL, F.W., and J.T. ERNEST, Ophtalmology : Principles and Concepts, 1974 [\$24.50], Mosby.

VAUGHAN, D., and T. ASHBURY, General Ophtalmology, 1977 [\$13.20], Lange.

- Orthopedics

ADAMS, J.C., Outline of Fractures, including Joint Injuries, 1972 [\$16.90], ChurchillLivingstone.

ADAMS, J.C., Outline of Orthopedics, 1976 [\$24.50], Churchill-Livingstone.

- Otorhinolaryngology

DEWEESE, D.D., and W.H. SAUNDERS, Textbook of Otorhinolaryngology, 1977 [\$19.40], Mosby. 
- Pathology

ANDERSON, W.A.D., and J.M. KISSANE, 1977, [\$45], Mosby.

BARRETT, James T., Textbook of Immunology : An Introduction to Immunochemistry and Immunobiology, 1978, 505 p. [\$18], C.V. Mosby Co.

ROBBINS, S.L., Pathologic Basis of Disease, 1974 [\$32.45], Saunders.

- Pediatrics

BARNETT, H.L., et al., Pediatrics, 1977 [\$48], Appleton-Century-Crofts.

HART, C.P., Child Care in General Practice, 1977 [\$19.95], Churchill-Livingstone.

ILLINGWORTH, R.C., Common Symptoms of Disease in Children, 1975 [\$15.50], Blackwell. VAUGHAN, V.C., et al., Nelson's Textbook of Pediatrics, 1975 [\$38.25], Saunders.

- Pharmacology and Therapeutics

- Compendium of Pharmaceuticals and Specialties, 1978 [\$27], Can. Pharm. Assoc.

CONN, H.F., Current Therapy, 1978 [\$28.05], Saunders.

GOODMAN, L.S., and A. GILMAN, Pharmacological Basis of Therapeutics, 1975 [\$37.50], Macmillan.

- Physiology

SODEMAN, W.A., jr., and W.A. SODEMAN, Pathologic Physiology : Mechanisms of Disease, 1974 [\$25.75], Saunders.

GUYTON, A.C., Textbook of Medical Physiology, 1976 [\$27.50], Saunders.

McCLINTIC, J. Robert, Physiology of the Human Body, 2nd Ed., 1978, 647 p. [\$21], W.

- Preventive Medicine and Public Health

CLARK, D.W., and B.W. MacMAHON, Preventive Medicine, 1967 [\$14.20], Little, Brown.

HART, C.R., Screening in General Practice, 1975 [\$18], Churchill-Livingstone.

- Psychiatry

FREEDMAN, A.M., et al., Modern Synopsis of Comprehensive Psychiatry, 1976 [\$30.75], Williams and Wilkins.

KOLB, L.C., Modern Clinical Psychiatry, 1977 [\$21.05], Saunders.

- Radiology

PAUL, L.W., and J.H. JUHL, Essentials of Roentgen Interpretation, 1972 [\$50], Harper and Row.

THOMPSON, T.T., Primer of Clinical Radiology, 1973 [\$15.50], Little, Brown.

- Research

ENGLAND, T.M., Medical Research, 1975 [\$8], Churchill-Livingstone.

HILL, A.B., Principles of Medical Statistics, 1971 [\$8.95], Oxford Univ. Press.

FRIEDMAN, G.D., Primer of Epidemiology, 1974 [\$13], McG-H.

- Sports Medicine

O'DONOGHUE, D.H., Treatment of Injuries to Athletes, 1976 [\$32.45], Saunders.

- Surgery

SABISTON, D.C., jr., Davis-Christopher Textbook of Surgery, 1977 [\$43.75], Saunders.

SCHWARTZ, S.I., et al., Principles or Surgery, 1974 [\$39.60], McG-H. 
- Urology

ROUS, S.N., Urology in Primary Care, 1976 [\$14.50], Mosby.

- General References

Dorland's Illustrated Medical Dictionary, 1974 [\$24.75], Saunders.

MILLER, B.F., and C.B. KEANE, Encyclopedia and Dictionary of Medicine, Nursing, and Allied Health, 1978 [\$19].

Blakiston's Gould Medical Dictionary, 3rd Ed., 19721500 p. [\$25], McG-H.

Blakiston's Pocket Medical Dictionary, 3rd Ed., 1973, 980 p. [\$12], McG-H.

Stedman's Medical Dictionary, 22nd Ed., 1975, 1533 p. [\$35], Williams and Wilkins.

Physics

AMERICAN INSTITUTE OF PHYSICS, American Institute of Physics Handbook, 3rd Ed., 1972,2200 p. [\$75], McG-H.

This new edition has been completely revised and updated to include new data on the earth's main magnetic field, surface geomagnetic variations, variations of space origin, ionosphere, magnetosphere, interplanetary medium, electrical fields, and wave phenomena.

ATKINS, Kenneth R., John R. HOLUM, and Arthur N. STRAHLER, Essentials of Physical Science, 1978, 546 p. [\$21.50], W.

BESANCON, R.M., Encyclopedia of Physics, 2nd Ed., 1080 p., 330 illus. [\$46.95], VNR. A commanding authority. Contains 344 articles supplemented by hundreds of charts, diagrams and other graphic aids.

COHEN, B., Concepts of Nuclear Physics, 1971, 448 p. [\$25], McG-H.

This introductory work on nuclear physics covers the standard topics. Features include an introduction to shell theory, the use of physical rather than mathematical reasoning wherever possible, and the emphasis on nuclear structure.

FREDRICK, L.W., and R.H. BAKER, Astronomy, 10th Ed., 576 p., illus. [\$21.95], VNR.

JAMES, A.M., A Dictionary of Thermodynamics, 1976, 262 p. [\$18], W.

This useful book contains definitions of the various quantities, tabulated thermodynamic data and provides access to standard reference texts for more detailed treatment. Partial contents : principle symbols, superscripts, subscripts, and other abbreviations.

JENKINS, F., and H. WHITE, Fundamentals of Optics, 4th Ed., 1976, 640 p. [\$24], McG-H.

McGraw-Hill Dictionary of Physics and Mathematics, 1978, 1074 p. plus appendix of 46 p., about 700 illus., McG-H. More than 20000 terms and definitions are presented. A commanding authority.

MITTON, Simon (Ed.), The Combridge Encyclopedia of Astronomy, 1977, 495 p. [\$45], Crown.

PASACHOFF, Jay M., and Marc L. KUTNER, University Astronomy, 1978, 835 p. [\$22.50], Saunders.

RESNICK, Robert, and David HALLIDAY, Physics, Part 1, 3rd Ed., 1977, 1224 p. (total) [\$20 ea.], W.

(HALLIDAY, David, and Robert RESNICK), Physics, Part 2, 3rd Ed., 1977 (cf. above).

Special Reference

ADAMS, D., and M. KURTZ, The Technical Secretary, 1968 [\$15], McG-H.

This book provides a systematic means for developing mastery of technical terminology and competence in technical dictation and transcription. 
BYERS, E., 10000 Medical Words, 1972, 128 p. [\$6], McG-H.

A handy reference for the correct spelling and syllabification of terminology encountered in the translator's office.

CLARK, R.L., and R.W. CUMLEY, The Book of Health, 3rd Ed., 1000 p., 1141 illus. [\$37.50], VNR.

This book provides up-to-date information on surgical operations, first aid, bodily functions, and disease symptoms and treatment.

CONSIDINE, D.M., Van Nostrand's Scientific Encyclopedia, 5th Ed., 2382 p., 2500 illus. [\$84.50], VNR.

A commanding authority.

FAIRBRIDGE, R.W., Encyclopedia of Atmospheric Sciences and Astrogeology, 1967, 1200 p., VNR.

FAIRBRIDGE, R.W., Encyclopedia of Geochemistry and Environmental Sciences, 1972 , 1321 p., VNR.

FAIRBRIDGE, R.W., Encyclopedia of Geomorphology, 1968, 1295 p., VNR.

FAIRBRIDGE, R.W., Encyclopedia of Oceanography, 1966, 1021 p., VNR..

These four encyclopedias, which make up the Encyclopedia of Earth Sciences Series (to consist eventually of eight volumes), are invaluable for the translator in these fields.

DE KERCHOVE, R., The International Maritime Dictionary, 2nd Ed., 1018 p., illus. [\$37.50], VNR.

Defines marine and nautical terms in the English language. All terms defined are followed by their French and German equivalents, which are also listed in complete French and German glossaries.

McGraw-Hill Basic Bibliography of Science and Technology, 1966, 738 p. [\$25], McG-H. This reference book lists and describes over 8000 outstanding books in every scientific and technical field. A topical index organizes all subject headings into about 100 general categories enabling the reader to locate quickly the listings which pertain to his field of interest.

McGraw-Hill Dictionary of Scientific and Technical Terms, 1974, 1600 p. [\$45], McG-H. This definite reference work for translators in scientific and technical fields contains over 100000 definitions. More than 3000 illustrations further clarify the descriptive entries in this volume.

QUICK, J., Dictionary of Weapons and Military Terms, 1973, 525 p., 1100 illus. [\$30], McG-H.

A valuable reference for military translators, this unique dictionary describes the principal weapons and weapon systems that have been used operationally from ancient times to the present day.

SABIN, W., The Gregg Reference Manual, 5th Ed., 1977, 300 p. [\$12], McG-H.

A manual providing up-to-date comprehensive coverage of the rules and principles of grammar, usage, and style.

SHAW, H., Dictionary of Literary Terms, 1972, 416 p. [\$20], McG-H.

This work defines, explains, and illustrates all literary terms, references, and allusions that today's translators are likely to encounter in reading any kind of literature including magazines and newspapers. It contains more than 2000 entries.

SHAW, H., Dictionary of Problem Words and Expressions, 1975, 288 p. [\$15], McG-H. This book has been designed to offer one convenient source where problem words and expressions are described, discussed, and illustrated with many examples of actual usage. 